\title{
CÓDIGO PENAL DO PCC: A LEI REAL DO NARCOTRÁFICO BRASILEIRO
}

\section{CCP PENAL CODE: THE REAL LAW OF BRAZILIAN DRUG TRAFFICKING}

WILLIAN HENRIQUE SILVA

Graduando em Direito, modalidade integral - Escola Superior Dom Helder Câmara. Belo Horizonte - MG. E-mail: willian.h.s163@gmail.com.

CAIO AUGUSTO SOUZA LARA Mestre e Doutor em Direito pela Faculdade de Direito da Universidade Federal de Minas Gerais - UFMG. Professor da Escola Superior Dom Helder Câmara. Pesquisador Associado ao Programa RECAJ-UFMG - Acesso à Justiça e Solução de Conflitos. Secretário de Comunicação do Conselho Nacional de Pesquisa e Pósgraduação em Direito - CONPEDI. Belo Horizonte-MG. E-mail: caiolarabh@yahoo.com.br.

\section{RESUMO}

O tema-problema da pesquisa que se pretende desenvolver é a estratégia utilizada pelo Primeiro Comando da Capital (PCC) para se tornar a maior facção criminosa da América Latina, conquistando um perigoso prestígio internacional no mundo do crime. A influência da efetividade do sistema estrutural do PCC, frente às outras facções, é notória. Prova disto é a evidente tentativa da Família do Norte em "mimetizar" a facção rival, e levar o exemplo bem-sucedido no mundo do crime em São Paulo para o norte do País, como observado no livro "A Guerra: A Ascensão do 
Personalidade Acadêmica Homenageada:

Raymundo Juliano Feitosa (Universidade Federal do Rio Grande do Norte - UFRN)

PCC e o Mundo do Crime no Brasil" (2018), de Bruno Paes Manso e Camila Nunes Dias. "Ô moleque, a questão não é quem vai ficar impune. A questão é que os dois não 'tirou' a vida do seu irmão. Tudo bem, eles 'tavam' na hora, mas eles não 'tirou' a vida do seu irmão, entendeu cara? Então, a gente é justo e correto. Entendeu moleque?", são as palavras gravadas a partir de uma interceptação telefônica entre membros do Primeiro Comando da Capital. Nota-se que o linguajar utilizado entre os criminosos, como "ético" e "justo", são termos contraditórios com o tipo de vida seguido pelos membros de facções criminosas. Similar às bases das Forças Armadas e Polícia Federal, instituições mais confiáveis do Brasil segundo o Datafolha (2014), que são a disciplina e hierarquia. Da mesma forma que é penalizado dentro das organizações militares, a quebra desse sistema hierárquico gera uma resposta dentro da cúpula do PCC. Porém, as penas são mais severas, como exemplo: uma punição conhecida entre os criminosos é o "xeque-mate" - esquartejamento prévio do infrator e, posteriormente, a sua morte - essa condenação é aplicada aos estupradores e pedófilos, também, tem por finalidade servir de exemplo para outros que teriam interesse em fazer o mesmo. O problema que gira em torno da pesquisa científica é: por que a organização de um sistema criminoso de grandes proporções se faz tão chamativo na sociedade contemporânea? A partir das reflexões prévias a respeito do tema a ser pesquisado, supõe-se que não é necessário apenas um aumento do investimento no sistema carcerário, tanto na infraestrutura, quanto na melhor qualidade de vida para com os presidiários e carcereiros, mas também um combate à estrutura do crime organizado que já está arraigado em muitos presídios no Brasil. Para que essa luta contra o crime seja efetiva é necessário o prévio conhecimento da consolidação dessa organização criminosa. O objetivo geral do trabalho é entender o sistema organizacional do Primeiro Comando da Capital e associá-lo com o aumento da criminalidade e do narcotráfico. A pesquisa que se propõe pertence à vertente metodológica jurídico-sociológica. No tocante ao tipo de investigação, foi escolhido, na classificação de Witker (1985) e Gustin (2010), o tipo jurídico-projetivo. O raciocínio desenvolvido na pesquisa será predominantemente dialético. De acordo com a técnica de análise de conteúdo, afirma-se que trata de uma pesquisa teórica, o que será possível a partir da análise de conteúdo dos textos doutrinários, normas e demais 
Personalidade Acadêmica Homenageada:

Raymundo Juliano Feitosa (Universidade Federal do Rio Grande do Norte - UFRN)

dados colhidos na pesquisa. Dráuzio Varella (2013) disse, em uma entrevista ao Portal Uol, que a população se faz por desatenta quando diz respeito ao tratamento dos presidiários, querem apenas as prisões dos delinquentes, não se importando se essas cadeias estarão lotadas ou não. Afirma também que "cadeia no Brasil não é para recuperar ninguém: é para fazer sofrer" (VARELLA, 2013). A partir do exposto, conclui-se que o PCC e outras facções criminosas foram criadas primordialmente quando houve violação sistêmica dos direitos humanos dos encarcerados. Contudo, em contradição aos seus propósitos, desrespeitam os direitos humanos daqueles que não aderem à mesma causa.

PALAVRAS-CHAVE: PCC; Facção Criminosa; Narcotráfico; Crime Organizado; Estado Paralelo.

\section{REFERÊNCIAS}

$78 \%$ das mortes têm relação com o tráfico de drogas, diz secretária de Segurança do RN. O Globo, 22 out. 2017. Disponível em: https://g1.globo.com/rn/rio-grande-donorte/noticia/78-das-mortes-tem-relacao-com-o-trafico-de-drogas-diz-secretaria-deseguranca-do-rn.ghtml. Acesso em: 10 de maio de 2019.

A ESCALADA das facções criminosas desafia o próximo presidente do Brasil. El Pais, São Paulo, $30 \quad$ ago. 2018 Disponível em: https://brasil.elpais.com/brasil/2018/08/16/politica/1534446775_776752.html. Acesso em: 09 de maio 2019.

CARVALHO, Cleide. Estatuto do PCC revela que 'preço da traição é a morte'. 0 Globo. Rio de Janeiro, 11 mar. 2018. Disponível em: https://oglobo.globo.com/rio/estatuto-do-pcc-revela-que-preco-da-traicao-a-morte22478005. Acesso em: 03 de maio de 2019.

ESTATUTO do PCC tem 18 artigos e código de ética. Istoé, 08 jan. 2017. Disponível em: https://istoe.com.br/estatuto-do-pcc-tem-18-artigos-e-codigo-de-etica/. Acesso em: 03 de maio de 2019.

FORÇAS Armadas e PF são instituições mais confiáveis. O Globo, 21 jul. 2014. Disponível em: http://g1.globo.com/politica/noticia/2014/07/forcas-armadas-e-pf-saoinstituicoes-mais-confiaveis-diz-datafolha.html. Acesso em: 09 de maio 2019. 
Personalidade Acadêmica Homenageada:

Raymundo Juliano Feitosa (Universidade Federal do Rio Grande do Norte - UFRN)

GUSTIN, Miracy Barbosa de Sousa; DIAS, Maria Tereza Fonseca. (Re)pensando a pesquisa jurídica: teoria e prática. $3^{3}$. ed. Belo Horizonte: Del Rey, 2010.

MANSO, Bruno Paes; DIAS, Camila Nunes. A Guerra: A Ascensão do PCC e o Mundo do Crime no Brasil. São Paulo: Todavia, 2018.

MANSO, Bruno Paes; DIAS, Camila Nunes. PCC, sistema prisional e gestão do novo mundo do crime no Brasil. Revista Forum. São Paulo v. 11, n. 2, 10-29, Ago/Set 2017.

OLIVEIRA, Cristina. Suspensão dos direitos políticos dos sujeitos delinqüentes no brasil: da negação da dignidade humana analisada sob o enfoque da cidadania participativa. Revista Jurídica - UNICURITIBA, Curitiba, v. 26, n. 10, 70-98, 2011. Disponível em: http://revista.unicuritiba.edu.br/index.php/RevJur/article/view/173/149. Acesso em: 22 de maio de 2019.

PCC tem estatuto com artigo que proíbe estupradores, homossexuais e pedófilos. Correio 24 horas, 08 jan. 2017. Disponível em: https://www.correio24horas.com.br/noticia/nid/pcc-tem-estatuto-com-artigo-queproibe-estupradores-homossexuais-e-pedofilos/. Acesso em: 04 de maio de 2019.

TRIBUNAL do Crime - PCC - Justiça paralela. Domingo Espetacular. Rede Record, 08 dez. 2007. Disponível em: https://www.youtube.com/watch?v=XVs9y1IXfZQ. Acesso em: 03 de maio de 2019.

VARELLA, Antônio Drauzio. Entrevista. São Paulo: 06 abr. de 2013. Entrevista concedida ao Portal Uol. Disponível em: https://noticias.uol.com.br/cotidiano/ultimasnoticias/2013/04/06/massacre-do-carandiru-foi-um-marco-mas-cadeias-ainda-naorecuperam-presos-diz-drauzio-varella.htm?cmpid=copiaecola. Acesso em: 08 de maio de 2019.

WITKER, Jorge. Como elaborar uma tesis en derecho: pautas metodológicas y técnicas para el estudiante o investigador del derecho. Madrid: Civitas, 1985. 